\title{
Natural hydrogen continuous emission from sedimentary basins: The example of a Brazilian H2-emitting structure
}

\author{
Alain Prinzhofer, Isabelle Moretti, Joao Francolin, Cleuton Pacheco, Ang \\ Elique D \\ apos;agostino, Julien Werly, Fabian Rupin, Angélique d'Agostino
}

\section{To cite this version:}

Alain Prinzhofer, Isabelle Moretti, Joao Francolin, Cleuton Pacheco, Ang Elique D

apos;agostino, et al.. Natural hydrogen continuous emission from sedimentary basins: The example of a Brazilian H2-emitting structure. International Journal of Hydrogen Energy, Elsevier, 2019, 44 (12), pp.5676-5685. 10.1016/j.ijhydene.2019.01.119 . hal-02187461

\section{HAL Id: hal-02187461 \\ https://hal-univ-pau.archives-ouvertes.fr/hal-02187461}

Submitted on 17 Jul 2019

HAL is a multi-disciplinary open access archive for the deposit and dissemination of scientific research documents, whether they are published or not. The documents may come from teaching and research institutions in France or abroad, or from public or private research centers.
L'archive ouverte pluridisciplinaire HAL, est destinée au dépôt et à la diffusion de documents scientifiques de niveau recherche, publiés ou non, émanant des établissements d'enseignement et de recherche français ou étrangers, des laboratoires publics ou privés. 


\title{
Natural hydrogen continuous emission from sedimentary basins: The example of a Brazilian $\mathrm{H}_{2}$-emitting structure
}

\author{
Alain Prinzhofer ${ }^{a, *}$, Isabelle Moretti ${ }^{b}$, Joao Françolin ${ }^{c}$, Cleuton Pacheco ${ }^{d}$, \\ Angélique D'Agostino ${ }^{e}$, Julien Werly ${ }^{e}$, Fabian Rupin ${ }^{e}$ \\ ${ }^{a}$ Geo4U, Rio de Janeiro, RJ, Brazil \\ ${ }^{\mathrm{b}}$ Engie SA, Paris, France \\ c GEORISK, Rio de Janeiro, RJ, Brazil \\ d Engie Brazil, Tubarão, SC, Brazil \\ e Engie Crigen SA, Courbevoie, France
}

\section{A R T I C L E I N F O}

Article history:

Received 18 October 2018

Received in revised form

31 December 2018

Accepted 10 January 2019

Available online $\mathrm{xxx}$

Keywords:

Natural hydrogen

Soil micro-seeps

Hydrogen geochemical soil moni-

toring

São Francisco basin

\begin{abstract}
A B S T R A C T
Hydrogen escaping from sedimentary basins has already been described in various parts of the world. Some of these leakages have been identified by superficial circular depressions, also called "fairy circles". Gas detection measurements, randomly repeated after a few months have shown that the amount of hydrogen present in soils is not constant neither versus time nor versus position in a given structure. Permanent monitoring gas analyzers were installed in the ground to estimate hydrogen flow outgassing from a topographical circular depression located in Brazil. Data show that a hydrogen flux occurs during the hottest moment of the day, as shown with permanent sensors set at a regular spacing. The process may look like a soil evaporation. In that same structure, other detectors show much higher and irregular gas output which present an unclear correlation as a function of ambient temperature and atmospheric pressure. The relationship with temperature suggests a role of water saturation driving the overall hydrogen fluxes. The reported geochemical data imply that (1) one measurement taken at a given hour on a structure cannot be considered as quantitative, as it varies too much with time and is also probably related to the soil perturbation induced by the shallow drilling, (2) hydrogen released through the soils of the studied structure is recharged daily, (3) hydrogen flux is high enough to reach the surface without being buffered by water or bacterial activity within the soil and (4) soil cannot be solely considered as a hydrogen sink but also, at least in some areas, as a hydrogen emitter. This appears to highlight that the subsurface may be considered in this site as a source of natural hydrogen, clearly differentiated from a biochemical system of atmospheric $\mathrm{H}_{2}$ consumed by bacteria.
\end{abstract}

\footnotetext{
* Corresponding author.

E-mail address: alain.prinzhofer@geo4u.com.br (A. Prinzhofer).
} 


\section{Introduction}

Hydrogen gas $\left(\mathrm{H}_{2}\right)$ has long been recognized as an energy vector. However, due to the abundance of oil and natural gas (i.e. methane) discoveries in the 20th century, this has substantially reduced hydrogen as an energy vector, especially for transports, although hydrogen engines were developed as early as the 19th century.

Recent awareness to reduce the world's carbon dependency has boosted the need for novel energy solutions, such as promoting hydrogen, partly because of its sole byproduct of combustion, water. Indeed, hydrogen gas can be oxidized without releasing any $\mathrm{CO}_{2}$ and transformed into electricity through fuel cells, and stored in large quantity as any gaseous component. Hydrogen which takes a large role in the industry as chemical raw material, thus becomes a key element in the energy mix, as an energy carrier and as fuel for transport.

Today, hydrogen is manufactured for a larger part (greater than $90 \%$ ) from hydrocarbons (mainly methane) by steam reforming and from water hydrolysis for most of the rest. The former process is rather cost efficient, by an approximate production cost of about $2 \$ / \mathrm{kg}$ [12]. Hydrolysis remains about 4 times more expensive, even if renewable electricity sources result in a low or even negative price of electricity at some hours of the day. Numerous companies, ENGIE for one and others that strive on governmental favorable Energy policies are elaborating original processes to decrease or even inverse the tendency and pave the way to produce "green hydrogen".

Technical incentives try to increase hydrogen's use in the energy mix and by that alleviate the present carbon footprint (see for instance the special issue "Pour la Science" of March 2018, [25]. Academic research has also been active to find other sources of hydrogen, from Syngas based on the catalysis of waste or using hydrogen producing bacteria or microalgae [32].

In order to obtain cost-effective $\mathrm{H}_{2}$ without using methane as the initial product, a different approach can be envisaged. Geologists have recently investigated natural hydrogen sources and whether they could be naturally produced [36]. Unexpectedly, the occurrence of hydrogen in continental shallow wells has been noted, as in Mali while drilling for water [37], in oil an gas exploration in Kansas, USA [13] or in basement rocks mines $[30,44]$. Monitoring of $\mathrm{H}_{2}$-enriched natural gases leaking from mines long existed in the Kola Peninsula in Russia to prevent accidents from happening, as such gas mixture is easily combustible and explosive $[29,30]$. Published studies have reported a non-permanent $\mathrm{H}_{2}$ concentration, interpreted in terms of free gas escaping associated to permeability changes in relation to pressure variations (mining activity, earthquake and possibly earth tide).

Hydrogen seepages have been described in the mid oceanic ridge $[5,22,51]$ and in onshore ophiolitic contexts $[1,2,10,28]$. Hydrogen has also been detected in sedimentary basins, in Russia [18] in the USA [52] and recently in Brazil [26]. Several articles are available on hydrogen monitoring in the soils in the vicinity of important geological fault zones, as evidenced in Japan [42,45], in Russia [11,30] and near the San Andreas Fault in California [43], to assess earthquake precursors. The monitoring of free gas and more generally fluid migrations in those setting have been extensively evaluated.

Researchers demonstrated that the stress changes before, during and after the ruptures, due to changes in the migration pathway of the fluids (see for instance Ref. [6] for the fluid changes and [9] for the pressure and overpressure changes in active fault zone). The authors working in seismically active areas evaluated the variability of the flow. They noticed $\mathrm{H}_{2}$ and fluid flow changes in relation with faults activity.

Gas seepage in continental areas has been observed in circular topographical depressions, of sometimes elongated shapes, in which hydrogen gas concentration can be detected and quantified. The following paper presents a geochemical monitoring of hydrogen in a topographical depression over few months. The area is located in the Brazilian craton in an area that is not seismically active. The geography, geology and topography will be investigated and discussed, followed by hydrogen flux estimations based on analytical data and modeling. The disruption resulting from repeated, continuous soil measurements will be discussed in a framework of understanding deep hydrogen generation and respective upward migration in shallow soils.

\section{Hydrogen seepage}

The study of onshore hydrogen seeps and hydrocarbon seeps is performed in a similar mode and with a same philosophy that is to evidence a deeper hydrogen system dynamically linked to $\mathrm{H}_{2}$ generation, migration, and possible accumulation and loss into the atmosphere. As a reminder, from comparable settings like a petroleum system, the overburden caprocks are not fully impermeable and often let hydrocarbons leak upward through sediments to the surface. The existence of seeps allows explorationist nonetheless to assume that mature source rock is or has been present. Despite this, hydrocarbon seeps are commonly located along faulted structures, whose damaged zones are easily understood as preferential migration pathways [24]. Liquid bitumen accumulating in tar ponds or in impregnate fault zones have been known for centuries. Their occurrences were taken as geochemical indicators for oil and gas exploration in the Middle East and in South America. Very sensitive apparatus today allows the detection of diffuse traces of volatile compounds in soils or sea bottoms [35]. Surface geochemistry has adequately shown its potential prior to oil and gas exploration and benefits from much lower cost/investments in unexplored frontier areas. The efficiency of surface geochemistry for hydrogen exploration is therefore investigated in this study, for a new and not well-known natural source of energy.

A conventional hydrocarbon system includes source rocks, permeable carrier bedrocks, structural trap/reservoir units and the presence of impermeable caprocks. Furthermore, to create petroleum accumulations, those different geological steps should synchronize with a right geological timing. Many rocks, including salts and shale for instance, are considered as efficient seals enabling hydrocarbon to accumulate in reservoirs for millions of years.

Presently, the concept of a $\mathrm{H}_{2}$ system being neither fully defined nor fully understood, the likelihood to trap $\mathrm{H}_{2}$ in the 
subsurface for long periods of time is not yet proven. The presence of low permeable rock beds, such as evaporites (halite for example) may capture $\mathrm{H}_{2}$ volumes in the subsurface. However, from the high diffusivity of hydrogen gas and its high chemical reactivity makes its preservation in rocks quite problematic in a geological time frame.

Concerning possible hydrogen sources, three main processes are envisioned (1) degassing from an original material [16] (2) water source rock interactions (i.e. REDOX chemical processes [23], or water destruction through radiolysis - [19] or crystal cracking - [42] and (3) bacterial origin [31,32]. Migration, carrier beds and reservoirs include most rocks containing a minimum of porosity and permeability. Due to solubility increase of $\mathrm{H}_{2}$ in water with pressure and temperature, another carrier phase can be evoked: water [20]. Although caprocks and seal efficiency have been debated, the mere occurrence of underground $\mathrm{H}_{2}$ storages in subsurface rock formations underlines a possible natural existence [33]. The only known areas of $\mathrm{H}_{2}$ production seem to be active processes, indicating that the associated impermeable seals only act as reducers of migration drive, allowing a gas steadystate type accumulation; as proof, the flow of hydrogen effluents out of middle oceanic ridges and those found in Oman "blue-pools" [49]. In another case, such as the continental Mali zone (Africa), $\mathrm{H}_{2}$ production has been active for the past 4 years, and the wellhead pressure is not indicating any substantial decrease with time, suggesting a continuous influx to the reservoir [37].

Known active $\mathrm{H}_{2}$ systems and continuous $\mathrm{H}_{2}$ seepage at the Earth's surface are characterized by the occurrence of bright, large scale "fairy circles". Several circular depressions have been described in Russia [17,18,46], in Mali [37] and in the United States [52]. In all these geographical locations, evidence of $\mathrm{H}_{2}$ in considerable concentrations in soils, from shallow drillings, were interpreted as $\mathrm{H}_{2}$ seeps concentrated in the circular depressions. Satellite images show that, at the time scale of a couple of years, such topographical depressions may appear or disappear [18].

Reported studies have shown that the $\mathrm{Fe}^{2+}$ oxidation state of iron is a good candidate to generate hydrogen by water/rock interaction [23]. Cratons are also good candidates because they contain unoxidized minerals. As a matter of fact, it has been observed so far that all the known $\mathrm{H}_{2}$ rich topographical depressions are located above or close to Proterozoic or older basements.

A circular depression located in Brazil was selected for an in-depth soil monitoring case study to investigate continuous hydrogen seeping versus space and time. Commercial tools to continuously monitor $\mathrm{H}_{2}$ fluxes were not available at the onset of the Brazilian survey. The ENGIE R\&D laboratory facility Crigen has developed an innovative detector to measure $\mathrm{H}_{2}$ concentrations in air, and in the soil porosity. Each sensor was calibrated in the laboratory with a reference standard gas containing $1000 \mathrm{ppm}$ of $\mathrm{H}_{2}$. The sensors are automatized and perform a measurement at a given frequency. Different parameters are sent real time to a database via a Gateway, that stacks data and transmits them via satellites. The hydrogen sensors are designed to work outdoors and endure varying temperatures and weather conditions and function in very remote areas. The sensors are connected to high performance batteries.

\section{The Brazilian case study}

The selection of a large circular structure located in the São Francisco Basin was made after a careful review of various basins in Brazil. The São Francisco basin is a Proterozoic aged structure, whose more recent sedimentary section (neo-Proterozoic Bambui Formation) has been extensively studied for hydrocarbon exploration (review in Ref. [39]). However, the deeper parts of the basin (older than Ediacaran, 635 million years) is poorly known, as only a few known drillings have been performed at these depths (over $1000 \mathrm{~m}$ ). Seismic profiles allow to propose an interpretation based on the extensions of geological formations outcropping eastward and westward at the borders of the basin within two thrust belts [38,39]. The geological formations have low porosity and have been explored for both conventional and unconventional resources. Some exploration wells in the area are listed as having encountered natural hydrogen while drillings but due to the lack of success to find hydrocarbons, these wells were abandoned.

The site is located in a dry and hot climate zone. Average temperatures go from $15{ }^{\circ} \mathrm{C}$ to a maximum of $35^{\circ} \mathrm{C}$ in afternoons. Daily sun light time is $12 \mathrm{~h}$.

The studied structure presents an area of about $600 \mathrm{~m}$ by $500 \mathrm{~m}$. Initial $\mathrm{H}_{2}$ concentrations detected by a GA5000 ${ }^{\circ}$ (from Geotech Comp.) portable analyzer outside of the structure's perimeter, and geochemical results presented consistent low concentrations (<10 ppm). Seven ENGIE Lab Crigen hydrogen analyzers were placed in the structure for several months during 2018. Detectors recorded hydrogen concentrations simultaneously in soils every hour. Soil measurements are made at shallow depths (less than $1 \mathrm{~m}$ ). Hydrogen sensors are initially calibrated with reference gases in laboratory, to provide accurate concentrations up to $2000 \mathrm{ppm}$. The gas is pumped through a $1 \mathrm{~cm}^{2}$ diameter probe, containing microapertures in the lower section. The pumping rate is similar to the $\mathrm{GA} 5000^{\circ}$ analyzer, enabling comparative sample runs. During the on-going monitoring of gas content in the structure, it is important to note that $\mathrm{H}_{2}$ concentrations are generally constant during the analyses time cycles ( $2 \mathrm{~min}$ ) and have been shown to oscillate $10-20 \%$ range in average. This point is analytically relevant, as it shifts from past $\mathrm{H}_{2}$ concentrations measured in soils studied by spot analyses $[18,52]$. This underlines the importance of a continuous monitoring approach for investigating soils saturated, or not, with gases. Observations from previous case studies showed that local $\mathrm{H}_{2}$ concentrations usually increased after positioning a probe in 1-m depth soils, up to a maximum given value, followed by a gradual decrease to zero value in a short time (few minutes).

The position of hydrogen sensors and reception antenna is shown on Fig. 1. The aerial photo shows very scarce vegetation within the depression as compared to the overall surrounding woodlands around the bare studied structure. As can be seen, two smaller satellite irregular depressions are visible in the upper part of the photograph which are not part of this survey. 


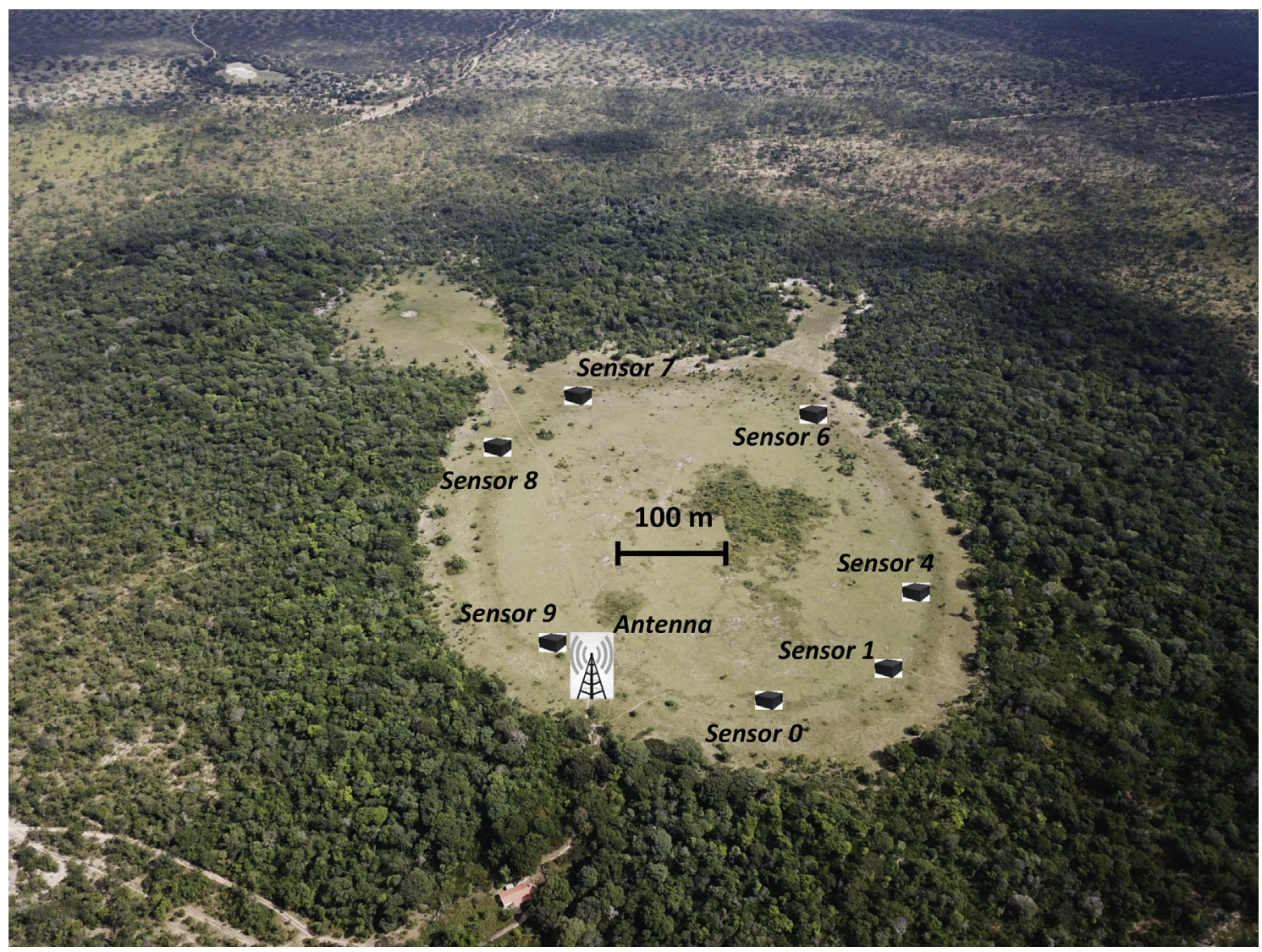

Fig. 1 - Photo of the location of $\mathrm{H}_{2}$ monitoring in a circular depression of the São Francisco Basin (Brazil). $\mathrm{H}_{2}$ sensors positions, and the data-transmitting antenna are shown.

\section{Geochemical measurements}

Prior to the extensive monitoring period, punctual hydrogen content was evaluated using a portable gas analyzer (GA5000 ${ }^{\circ}$ from Geotech Comp.). The analyses were performed in a loose grid, crisscrossing the depression, in soils sampled at a 1-m depth using a copper tube inserted in the ground and pumping air through the analyzer for 1-min cycles, as detailed in published papers from studies done in other continental sites $[18,52]$. The spot analyses, at the position of each permanent sensors using the $\mathrm{GA} 5000^{\circ}$ detector, are presented Table 1 and serve as comparative time-fixed hydrogen gas readings. The respective data have all been obtained by following the same analytical protocole, i.e. perforating close to a 1-m deep hole,

Table $1-\mathrm{H}_{2}$ concentrations analyzed by $\mathbf{G A 5 0 0 0 ^ { \odot }}$ portable analyzer.

\begin{tabular}{lc} 
Sensor $\mathrm{N}^{\circ}$ & $\mathrm{H}_{2}$ initial $(\mathrm{ppm}) \mathrm{GA5000} \odot$ \\
\hline 0 & 541 \\
1 & 412 \\
4 & 221 \\
6 & 401 \\
7 & 451 \\
8 & 310 \\
9 & 319 \\
\hline
\end{tabular}

inserting a probe and while pumping air, measuring hydrogen concentration levels. The $\mathrm{GA}_{5} 000^{\circ}$ analyzer measured repeatedly low $\mathrm{H}_{2}$ content in the structure center and higher readings at its border. This explains why initially, permanent detectors were located around the structure in order to capture maximum $\mathrm{H}_{2}$ signals.

Following a short monitoring test period to check detectors reading stability, a permanent gas monitoring was begun in July 2018. Figs. 2-6 refer dates of this year.

The first comment from data, is that the permanent analyzers are consistent in gas readings, but however, also somewhat complex to interpret: six out of seven sensors present regular, Gaussian-shape-time distributions of emission with a daily periodicity (Fig. 2 presents a detail of the monitoring during 7 days), centered at noon (local time). The intensity of the hydrogen spikes occurs for nearly 5-6 continuous hours. Intensities return to baseline levels during the night time, except for sensor \#4, which presents at the end of a $24 \mathrm{hr}$ period, a smaller and coalescent peak occurring during night time (yellow line on Fig. 2). It is interesting to note that a similar periodicity has been already reported in the San Andreas and Calaveras faults zones in California [43], although hydrogen concentrations in this work do not decrease to the zero values at nights. This may be due (as seen for sensor \#4) to a memory effect. The generally good agreement of hydrogen trends for $24 \mathrm{~h}$ periods in two very different geological environments (large seismic faults, and aseismic 


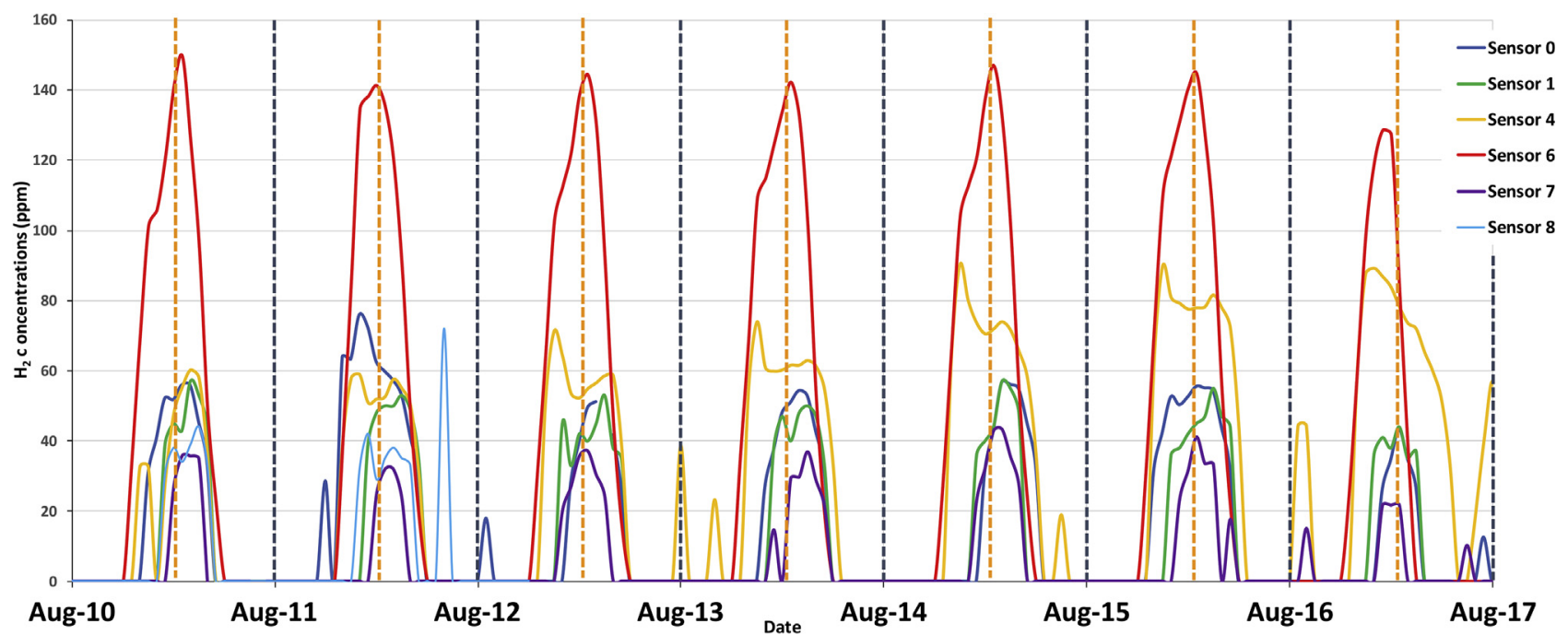

Fig. 2 - Week-long $\mathrm{H}_{2}$ monitoring in soils of the studied structure of sensors \#0, 1, 4, 6, 7 and 8. Concentrations are in ppm. The dashed vertical grey lines indicate midnight. The dashed vertical orange lines indicate midday. Sensors \#2, 3 and 5 were not presented in this Figure. (For interpretation of the references to colour in this figure legend, the reader is referred to the Web version of this article.)

area with a circular depression, without any visible fault) highlights some general geological process, however not fully understood so far.

A temperature probe is included in the ENGIE analyzers. Nonetheless, local meteorological station provided additional key and relevant parameters that were used (temperature, air pressure, wind velocities, precipitation, sun radiation). Figs. 3 and 4 plot these external data. Pressure, wind and rain parameters were not included since they remained relatively constant during the monitoring period. The reader may have access to full data from the internet site http://www.inmet.
gov.br/sonabra/pg_dspDadosCodigo_sim.php?QTUONw $==$. Hydrogen content from soil emissions were generally well correlated with observed solar radiation (Fig. 3).

Sensor \#9 presented strikingly different behavior in hydrogen gas concentrations versus time throughout the entire monitoring survey. Sensor \#9 showed no straightforward correlation with atmospheric radiation (nor temperature) whereas the respective gas concentrations were variable, from null initially to values as high as $1150 \mathrm{ppm}$ (Fig. 4).

A moving average of hydrogen concentrations (on 7 days) is shown on Fig. 5, to smoothen curves. The hydrogen content,

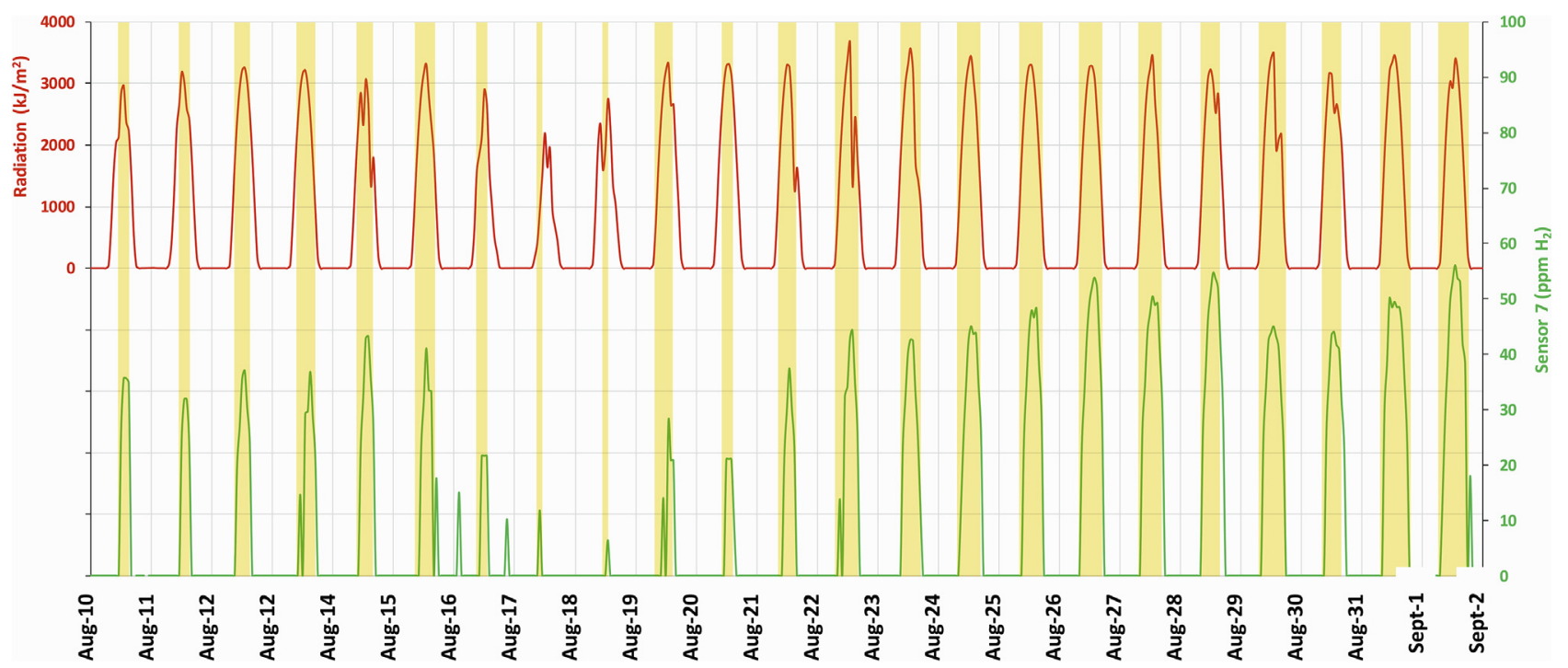

Fig. 3 - Time variations evaluated during 23 days of monitoring of the $\mathrm{H}_{2}$ concentrations in sensor \#7 (in parts per million, shown in green) combined with local atmospheric radiation shown in red (in $\left.\mathrm{kJ} / \mathrm{m}^{2}\right)$. The yellow bars correspond to the peaks of solar radiation versus time. (For interpretation of the references to colour in this figure legend, the reader is referred to the Web version of this article.) 


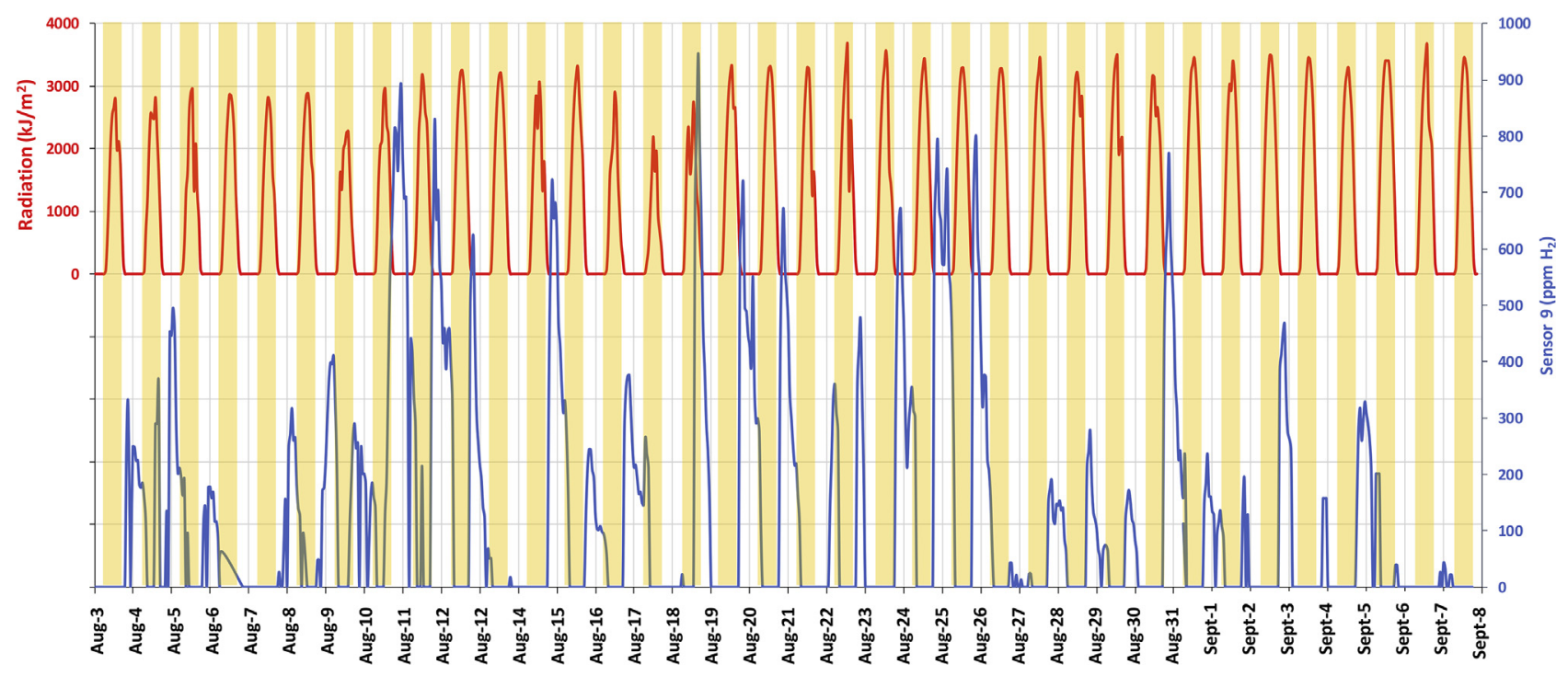

Fig. 4 - Irregular hydrogen gas concentrations (in blue) in parts per million (ppm) analyzed every hour at sensor \#9 as a function of time (36 days). In red, atmospheric radiation (in $\mathrm{kJ} / \mathrm{m}^{2}$ ) for the same period. Yellow bands correspond to the peaks of solar radiation versus time. (For interpretation of the references to colour in this figure legend, the reader is referred to the Web version of this article.)

measured by detector \#9 presents a logic of emission which is associated to different and unknown physical processes. Fig. 5 presents the comparison of the curve of concentrations versus time for the raw data and for the moving average. The difference between raw data and calculated moving average is small for the emissions recorded during the day (example of the sensor \#6). On the contrary, sensor \#9 presents very scattered raw $\mathrm{H}_{2}$ emission peaks.

\section{Discussion}

\section{Daily cycle}

The $\mathrm{H}_{2}$ emission from this case study follows temperature and irradiation curves in almost all permanent sensors. The solar radiation is known to be responsible for the soil evaporation $[47,50]$. This points out that hydrogen emissions likely follow an evaporation mechanism, even if the relationship between water evaporation in soils and hydrogen leakage is not clearly understood. As a matter of fact, one could say that the amount of daily evaporated soil moisture cannot fully explain the hydrogen liberation observed, even if one assumes fully hydrogen saturated water droplets. In this respect, the amount of hydrogen would be less (Lopez-Lazaro et al., submitted). Moreover, the water saturation in soils down to the piezometric level (upper level of the water table) is quite low due to the dryness of the area, and reflected in the monitoring months during the dry season, as the soils are mainly sandy. It could be said that molecular hydrogen adsorption in clay minerals in soils is decreased in sufficient amount to account for analyzed hydrogen content [48], although no real quantification of this process is available to support the idea. The important point to be made is that from current data, hydrogen in soils in the structure is recharged daily, implying a source of hydrogen generation below the surface gas seeps. The same observation was made in the San Andreas Fault area [43]. Because the observation was made from a highly seismic area, it induced a tentative correlation between earthquakes and $\mathrm{H}_{2}$ generation/migration. However, the Sao Francisco Basin is aseismic [4] and therefore, the explanation of [43] for an equivalent phenomenon is not convincing [30]. showed $\mathrm{H}_{2}$ concentration in the mines of Kola Peninsula in Russia with different signal wavelengths including a diurnal periodicity; the harmonic oscillation is not as regular as the one measured in the Brazilian case study, and authors interpreted the former in terms of the cyclic nature of the mining operations. Anthropic activities cannot be proposed to explain the data collected in Brazil and presented in this paper, since there is no industry or mines in the area. Conversely, data from USA and Russia and the presence of a diurnal periodicity should be revised in the light of the new data set.

A different pattern is seen in sensor \#9, located in the southern border of the structure and exhibiting large and scattered emissions. A possible interpretation is a hydrogen discharge in concomitance with evaporation that creates a buffering of the emission through a physical process involving a different soil composition (affected by water and clay mineral content for instance). In that eventuality, the recording of sensor \#9 may correspond to a more direct emission of hydrogen already in a vapor phase, without any soil buffering. This would explain the higher concentrations as well as the larger scattering of the concentrations.

At this point in time, it can be proposed that although hydrogen is generally thought to be mainly consumed by soils which act like a sink $[8,14,34,40]$, this case study seems to demonstrate that soils within the particular circular structure act like a hydrogen emitter. 

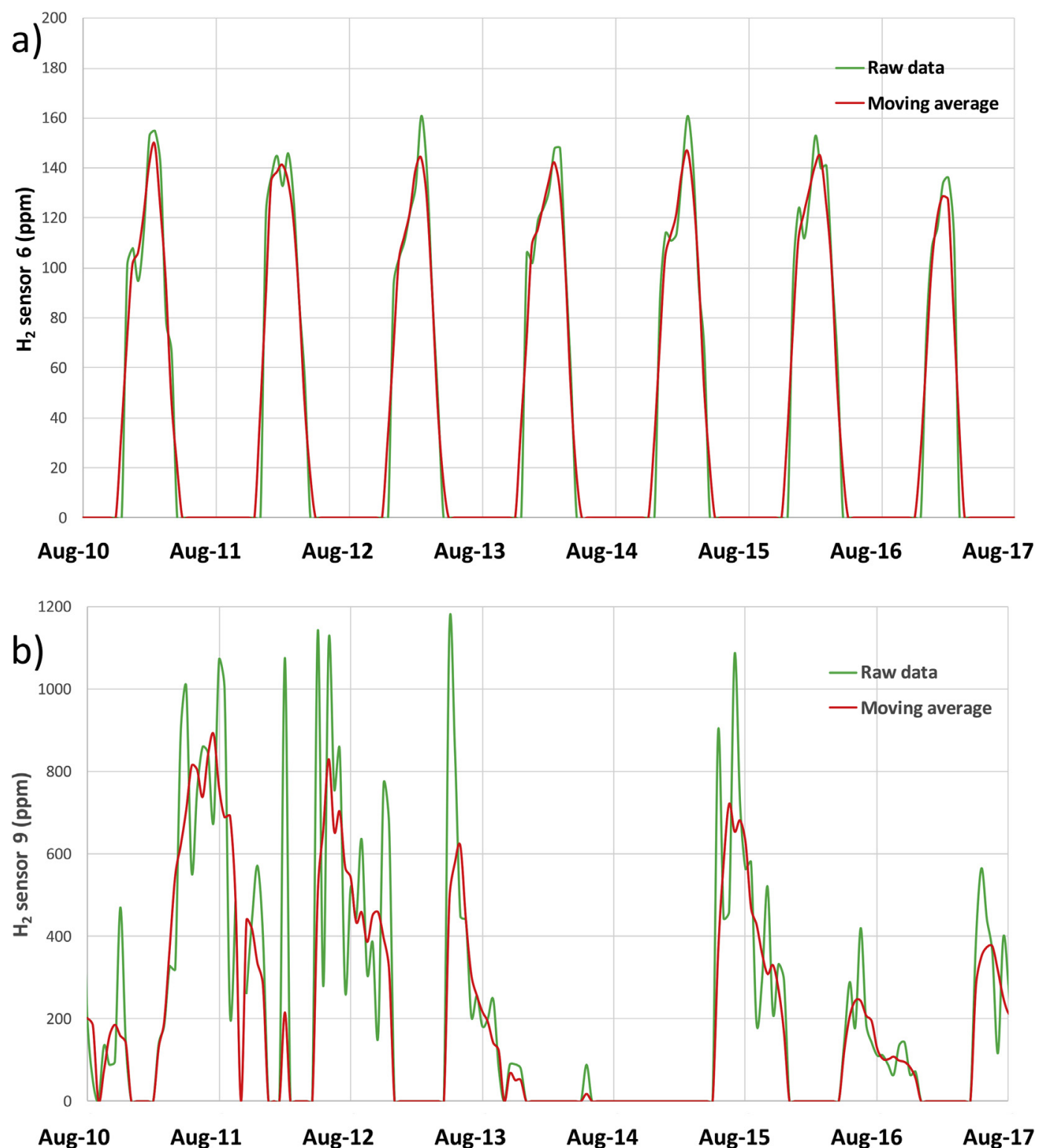

Fig. 5 - Difference between raw data and calculated moving averages (on 5 points) of measured hydrogen concentrations (in ppm) monitored at sensors \#6 (top) and \#9 (bottom). The data represent 7 monitoring days between August 10th to August 17th.

\section{Quantity of $\mathrm{H}_{2}$ emitted}

Industrial production of the natural $\mathrm{H}_{2}$ will be feasible if the flow is permanent and large. It is possible to deduce some daily volume from such measurements. Fig. 6 presents an accumulated hydrogen amount for each of the detectors. A volume of hydrogen passing through the devices was calculated, considering a $400 \mathrm{ml} / \mathrm{min}$ pump rate for each detector. Taking into consideration a reduced pumping time of $2 \mathrm{~min}$ per hour and the fact that almost no variation of the $\mathrm{H}_{2}$ concentration is seen is in agreement with the hypothesis made. Although sensor \#9 presents an initial delay in terms of amount of emitted $\mathrm{H}_{2}$, after some days, it becomes the most productive part of the studied area. For this sensor, the cumulated value reaches about $3 \mathrm{~L}$ in 40 days. It is also apparent from Fig. 6 that rather quickly, all the sensors present parallel trends of concentration versus time. Although different, calculated trends are consistent among all the sensors.

Considering a drainage area of $1 \mathrm{~cm}^{2}$ for sensor \#9, this induces a resulting large flux if extrapolated to the whole structure: from a simple calculation, the local flux rate can be estimated to be around $178,000 \mathrm{~m}^{3}$ of $\mathrm{H}_{2}$ per day. If a larger cross-section is taken, which influences an area of $25 \mathrm{~cm}^{2}$, the global flux is respectively reduced to about $7000 \mathrm{~m}^{3}$ of $\mathrm{H}_{2}$ per day, with the same hypothesis of a homogenous deeper flux.

In literature, soils are always considered as hydrogen sinks with atmospheric hydrogen concentration around $0.5 \mathrm{ppm}$, mainly generated by photoproduction from $\mathrm{H}_{2} \mathrm{O}$ and $\mathrm{CH}_{4}$ [3], and is being consumed by microbial life in soils $[7,8,14,34,40]$. 


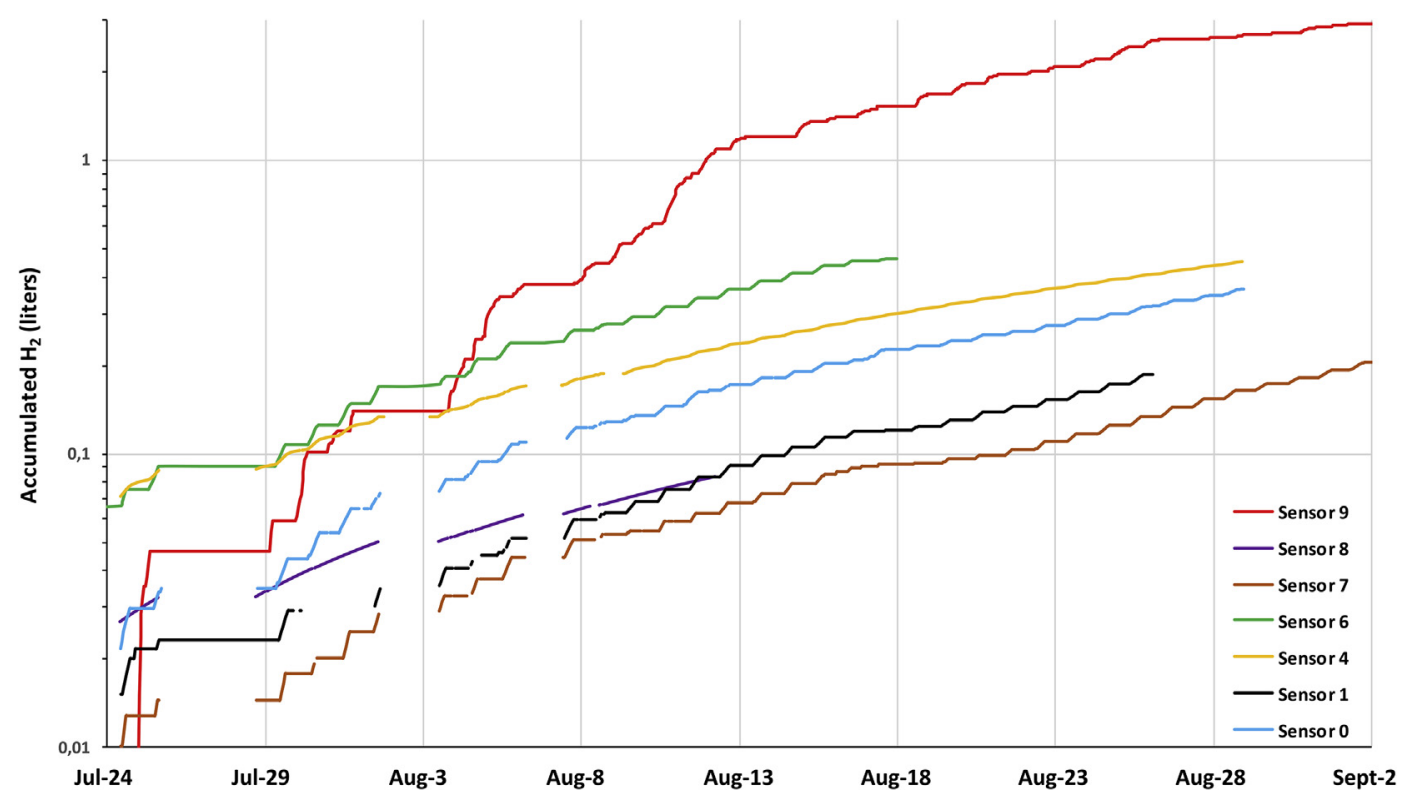

Fig. 6 - Cumulated $\mathrm{H}_{2}$ amount (in liters) versus time during $\mathbf{4 0}$ days of monitoring. The hypotheses for this calculation are presented in the text (volume of $\mathrm{H}_{2}$ passing through each sensor, i.e. though a $1 \mathrm{~cm}^{2}$ diameter tube with a flow of $400 \mathrm{ml} /$ $\min )$.

It is extensively referenced that microbiology in soils also generates molecular hydrogen, as the first source of energy for life without possibility of photosynthesis [31]. However, the measured concentrations from biological culture of nitrogenase organisms are generally minor (in the best case scenario, [31]; measure 90 ppm in their experiments, without any posterior biological consumption of the generated $\mathrm{H}_{2}$ ). The absence of measurable $\mathrm{CO}_{2}$ (as reported from the $\mathrm{GA} 5000^{\circ}$ portable gas analyzer) associated with $\mathrm{H}_{2}$ (which would possibly indicate a biological respiration) and the observation of above atmospheric ( $5 \mathrm{ppm}$ ) helium concentrations favors the marginal effect of biological hydrogen generation. This suggests a possible gas migration from deeper horizons, where helium is generated.

This study effectively underlines that the ground is acting as a hydrogen emitter in the analyzed structure, possibly changing the global estimated $\mathrm{H}_{2}$ fluxes (photochemical production, biomass burning, fossil energy combustion for production, biological and chemical reactions, [40]. The estimated flux leaking out to the surface may be quite important here, and if a soil is indeed a hydrogen consumer, the real flux before its dispersion in air is even higher. Hydrogen consumption has been measured in this particular soil as $4.3 \mathrm{l} /$ day. $\mathrm{m}^{3}$ [27]. The piezometric level is at a depth of $3 \mathrm{~m}$, Assuming a drainage radius of $25 \mathrm{~cm}^{2}, \mathrm{H}_{2}$ consumption is close to $32 \mathrm{ml} /$ day. If the flux measured by the sensor \#9 ( $75 \mathrm{ml} /$ day) is corrected from hydrogen consumption, the real flux of $\mathrm{H}_{2}$ would be $107 \mathrm{ml} /$ day, i.e. 43\% higher than the measured one.

As a conventional soil is a $\mathrm{H}_{2}$ consumer, and as some wells located near the studied area (at depth around $1500 \mathrm{~m}$ ) quantified $\mathrm{H}_{2}$ concentration in a gas phase around $40 \% \mathrm{~mol} /$ mol, this indicates a likely deeper source of $\mathrm{H}_{2}$ generation. In that scenario, hydrogen percolates through layers of rocks, reaching the soils and seeping into the air as tentatively demonstrated here. Considering the sink effect of a soil for hydrogen, the estimated flux from our monitoring is a lower limit, because a part of the migrating hydrogen is probably consumed when traversing sediments.

\section{Conclusions}

The physical process of hydrogen migration through the soils seems complex. Based on the present case study, some hydrogen analyzers register a hydrogen content correlated with actual soil evaporation mechanisms, with hydrogen content varying from 40 to $200 \mathrm{ppm}$ in different sensors around a circle structure. One sensor presents a similar regular emission, but in the last days of monitoring, a secondary intense signal coalesced with the midday peak during nights. Finally, one sensor recorded night emissions, in larger amount (up to $1150 \mathrm{ppm}$ ) and little during days, and a higher oscillations of hydrogen concentrations versus time. These field observations indicate that the hydrogen molecule is seeping out of the soils with probably several physical processes and media. First, considering the media where hydrogen may be stored, a desorption process out of the water liquid phase is viable, with hydrogen mobilizing directly in a vapor phase, or being desorbed out of mineral surfaces like clay minerals. The dynamic process of hydrogen transport may be pure diffusion [15], advection [21], or of mix of diffusion and advection [41]. At this time, it is difficult to assess the relative importance of these different processes for the $\mathrm{H}_{2}$ molecule, but the consistently different hydrogen emissions observed at a small scale of a single circular structure nonetheless show the complexity of hydrogen leakage mechanisms to the subsurface. 


\section{Acknowledgement}

This project is being developed under the Research and Development Program of ENGIE Brasil Energia, regulated by the National Electric Energy Agency (ANEEL). We thank especially Carlos Ghost, Alexandre Zucarato, Emmanuel Delfosse from Engie Brasil Energia. Diane Defrenne participated actively to its launch. At Engie lab Crigen, the sensors have been developed with the help of Louis Gorintin. We thank Fabrice Brunet and Andrey Miagkiy (Isterre Grenoble) for very interesting discussion and a flavor of the first results on the bacterial activity in the soil. We are also grateful to Caroline Magnier and Jan Mertens for a prereview of the paper. Three anonymous reviewer improved substantially the initial manuscript.

\section{REFEREN C E S}

[1] Abrajano TA, Sturchio NC, Bohlke JK, Lyon GL, Poreda R, Stevens C. Methane-hydrogen gas seeps, Zambales Ophiolite, Philippines: deep or shallow origin? Chem Geol 1988;71(1-3):211-22. https://doi.org/10.1016/0009-2541(88) 90116-7.

[2] Abrajano TA, Sturchio NC, Kennedy BM, Lyon GL, Muehlenbachs K, Bohlke JK. Geochemistry of reduced gas related to serpentinization of the Zambales ophiolite, Philippines. Appl Geochem 1990;5(5-6):625-30. https://doi. org/10.1016/0883-2927(90)90060-I.

[3] Amouyal E. Photochemical production of hydrogen and oxygen from water: a review and state of the art. Sol Energy Mater Sol Cell 1995;38:249-76.

[4] Assumpçao M, Vieira Barros L, França GS, Menezes EAS, Pirchiner M, Dourado JC, Ferreira J, Bezerra FHR, Barbossa JR, Ribotta LC, Farias do Nascimento A. Intraplate seismicity in Brazil. In: Talwani P, editor. Intraplate earthquakes; 2014. p. 50-71. https://doi.org/10.1017/CBO9781139628921.004 [Chapter 3].

[5] Charlou JL, Donval JP, Fouquet Y, Jean-Baptiste P, Holm N. Geochemistry of high $\mathrm{H}_{2}$ and $\mathrm{CH} 4$ vent fluids issuing from ultramafic rocks at the Rainbow hydrothermal field ( $36^{\circ} 14^{\prime} \mathrm{N}$, MAR). Chem Geol 2002;191:345-59.

[6] Ciotoli G, Guerra M, Lombardi S, Vittori E. Soil gas survey for tracing seismogenic faults: a case study in the Fucino Basin, Central Italy. J Geophys Res 1998;103:23781-94.

[7] Conrad R, Seiler W. Influence of temperature, moisture, and organic carbon on the flux of $\mathrm{H}_{2}$ and $\mathrm{CO}$ between soil and atmosphere: field studies in subtropical regions. J Geophys Res 1985;90(D3):5699-709.

[8] Constant P, Chowdhury SP, Hesse L, Conrad R. Colocalization of atmospheric $\mathrm{H}_{2}$ oxidation activity and high affinity $\mathrm{H} 2$-oxidizing bacteria in non-axenic soil and sterile soil amended with Streptomyces sp. PCB7. Soil Biol Biochem 2011;43. 1888-18.

[9] Cornet FH, Doan ML, Moretti I, Borm G. Drilling through the active Aigion Fault: the AIG10 well observatory. CRAS Struct Geol Deform Mech 2004;336:395-406.

[10] Deville E, Prinzhofer A. The origin of $\mathrm{N}_{2}-\mathrm{H}_{2}-\mathrm{CH}_{4}$-rich natural gas seepages in ophiolitic context: a major and noble gases study of fluid seepages in New Caledonia. Chem Geol 2016;440:139-47.

[11] Firstov PP, Shirokov VA. Dynamics of molecular hydrogen and its relation to deformational processes at the Petropavlovsk-Kamchatskii geodynamic test site: evidence from observations in 1999-2003. Geochem Int
2005;43:1056-64. No 11 Translated from Geokhimiya No 11, 2005, P. 1151-1160.

[12] Grab-Rogalinski K, Szwaja S. Cost analysis of hydrogen energy generation. Journal of KONES Powertrain and Transport 2014;21(3):121-6. No.

[13] Guélard J, Beaumont V, Rouchon V, Guyot F, Pillot D, Jézéquel D, Ader M, Newell KD, Deville E. Natural $\mathrm{H}_{2}$ in Kansas: deep or shallow origin? AGU publications, frontiers in geosystems: deep earth - surface interactions. Geochem Geophys Geosyst 2017;18:1-25. https://doi.org/10.1002/ 2016GC006544.

[14] Khdhiri M, Hesse L, Popa ME, Quiza L, Lalode I, Meredith LK, Röckmann T, Constant P. Soil carbon content and relative abundance of high affinity $\mathrm{H}_{2}$-oxidizing bacteria predict atmospheric $\mathrm{H}_{2}$ soil uptake activity better than soil microbial community composition. Soil Biol Biochem 2015;85:1-9.

[15] Kimball BA, Lemon ER. Air turbulence effects upon soil gas exchange. Soil Sci Soc Am Proc 1971;35. № 1, Januaryfebruary 1971.

[16] Larin N. Hydridic Earth. The new geology of our primordially hydrogen-rich planet. In: Warren Hunt C, editor. Translation. Calgary, Alberta, Canada: Published by Polar Publishing; 1993. 247p.

[17] Larin NV, Larin VN, Gorbatikov AV. Circular structures, caused by the deep seeping 511 of hydrogen. In: Degassing of the Earth: geotectonics, geodynamics, Deep Fluids, oil and gas; 512 hydrocarbons and life. Russian conference with international participation dedicated to the 513 100th anniversary of academician P.N. Kropotkin; 2010. p. 282 [in Russian)].

[18] Larin N, Zgonnik V, Rodina S, Deville E', Prinzhofer A, Larin VN. Natural molecular hydrogen seepages associated with surficial, rounded depression on the European craton in Russia. Nat Resour Res 2015;24(3):363-83. https://doi.org/10. 1007/s11053-014-9257-5.

[19] Lin LH, Slater GF, Sherwood-Lollar B, Lacrampe-Couloume B, Onstott TC. The yield and isotopic composition of radiolytic H2, a potential energy source for the dep subsurface biosphere. Geochem Cosmochim Acta 2005;69:893-903.

[20] Lopez-Lazaro C, Bachaud P, Moretti I, Ferrando N. Hydrogen solubility in aqueous $\mathrm{NaCl}$ solutions: from molecular simulation to equation of state. Submitted to Int J Hydrogen Energy 2018.

[21] Maier M, Schack-Kirchner H, Aubinet M, Goffin S, Longdoz B, Parent F. Turbulence effect on gas transport in three contrasting forest soils. Soil SciSocAm J 2011;76:1518-28.

[22] Marcaillou C, Muñoz M, Vidal O, Parra T, Harfouche M. Mineralogical evidence for $\mathrm{H}_{2}$ degassing during serpentinization at $300{ }^{\circ} \mathrm{C} / 300$ bar. Earth Planet Sci Lett 2011;303(3-4):281-90. https://doi.org/10.1016/j.epsl.2011.01. 006.

[23] Milesi V, Guyot F, Brunet F, Richard L, Recham N, Benedetti M, Dairou J, Prinzhofer A. Formation of $\mathrm{CO}_{2}, \mathrm{H}_{2}$ and condensed carbon from siderite dissolution in the $200-300^{\circ} \mathrm{C}$ range and at $50 \mathrm{MPa}$. Geochem Cosmochim Acta 2015;154:201-11.

[24] Moretti I, Labaume P, Sheppard S, Boulègue J. Compartmentalization of the migration pathways in the subandean zone, Bolivia. Proceeding of Geofluid 2000, Barcelona Tectonophysics 2002;348:5-24.

[25] Moretti I, Pierre H. Pour la Science, special issue in partnership with Engie, vol. 485; 2018. p. 28. $N^{\circ}$ march.

[26] Moretti I, D'Agostino A, Werly J, Ghost C, Defrenne D, Gorintin L. Pour la Science, special issue in partnership with Engie, march 2018. 2018. 24-25XXII_XXVI.

[27] Myagkiy A, Brunet F, Sissmann O, Popov C, Krüger R, Charlet L, Moretti I. Experimental study of H2 consumption 
by soils from the Sao Francisco Basin (Minas Gerais, Brazil): implications for continental H2 exploration. 2019 (in prep.).

[28] Neal C, Stanger G. Hydrogen generation from mantle source rocks in Oman. Earth Planet Sci Lett 1983;66:315-20. https:// doi.org/10.1016/0012-821X(83)90144-9.

[29] Nivin VA. Free hydrogen-hydrocarbon gases from the Lovozero loparite deposit (Kola Peninsula, NW Russia). Appl Geochem 2016;74:44-55.

[30] Nivin VA, Pukha VV, Lovchikov AV, Rakhimov RG. Changes in the molecular hydrogen concentration in an underground mine (Lovozero rare-metal deposit, Kola peninsula). Dokl Earth Sci 2016;471(2):1261-4.

[31] Noar j, Loveless T, Navarro-Herrero JL, Olson JW, BrunoBarcena JM. Aerobic hydrogen production via nitrogenase in Asotobacter vinelandii CA6. Appl Environ Microbiol 2015;81:4507-16. No 13.

[32] Oey M, Sawyer AL, Ross IL, Hankamer B. Challenges and opportunities for hydrogen production from microalgae. Plant Biotechnol J 2016;14:1487-99.

[33] Panfilov M. Underground and pipeline hydrogen storage. Compend Hydrogen Energy 2016:91-115. https://doi.org/10. 1016/B978-1-78242-362-1.00004-3 Elsevier Ltd.

[34] Piché-Choquette S, Khdhiri M, Constant P. Dose-response relationships between environmentally-relevant $\mathrm{H}_{2}$ concentrations and the biological sinks of $\mathrm{H}_{2}, \mathrm{CH}_{4}$ and $\mathrm{CO}$ in soil. Soil Biol Biochem 2018;123:190-9.

[35] Price LC. Research-derived insights into surface geochemical hydrocarbon exploration. In: Schumacher D, Abrams MA, editors. Hydrocarbon migration and its near-surface expression: AAPG Memoir 66; 1996. p. 285-307.

[36] Prinzhofer A, Deville E. Hydrogène naturel. La prochaine révolution énergétique? Edition Belin. 2015. p. 187p (13th of May 2015).

[37] Prinzhofer A, Cissé CST, Diallo AB. Discovery of a large accumulation of natural hydrogen in Bourakebougou (Mali). Int J Hydrogen Energy 18 October 2018;43(42):19315-26.

[38] Reis HLS. Neoproterozoic evolution of the São Francisco basin, SE Brazil: effect of tectonic inheritance on foreland sedimentation and deformation. PhD defended on July 2016. Brazil: University of Ouro Preto; 2016.

[39] Reis HLS, Alkmim FF, Fonseca RCS, Nascimento TC, Suss JF, Prevatti LD. The são Francisco Basin. Chapter from book "São Francisco Craton, Eastern Brazil: tectonic genealogy of a miniature continent". 2017. p. 117-43.

[40] Rhee TS, Brenninkmeijer CAM, Röckmann T. The overwhelming role of soils in the global atmospheric hydrogen cycle. Atmos Chem Phys Discuss 2005;5:11215-48.

[41] Rhino K, Loisy C, Cerepi A, Le Roux O, Garcia B, Rouchon V, Noirez S, Le Gallo C, Delaplace P, Willequet O, Bertrand C, El Khamlichi A. The demo-CO2 project : monitoring and comparison of two shallow subsurface $\mathrm{CO}_{2}$ leakage experiments with gas tracer associated in the carbonate vadose zone. Int J Greenhouse Gas Control 2016;53:207-21.

[42] Satake H, Ohashi M, Hayashi Y. Discharge of H2 from the Atotsugawa and Ushibi faults, Japan, and its relation to earthquakes. Pageoph 1985;122:185-93.

[43] Sato M, Sutton AJ, McGee KA, Russel-Robinson S. Monitoring of hydrogen along the san Andreas and Calaveras faults in central California in 1980-1984. J Geophys Res 1986;91:12315-26. N B12.

[44] Sherwood Lollar B, Lacrampe-Couloume G, Voglesonger K, Onstott TC, Pratt LM, Slater GF. Isotopic signatures of CH4 and higher hydrocarbon gases from Precambrian sheld sites: a model for abiogenic polymerization of hydrocarbons. Geochem Cosmochim Acta 2008;72:4778-95.

[45] Sugisaki R, Ido M, Takeda H, Isobe Y, Hayashi Y, Nakamura N, Satake H, Mizutani Y. Origin of hydrogen and carbon dioxide in fault gases and its relation to fault activity. J Geol 1983;3:239-58. No.

[46] Sukhanova NI, Trofimov SY, Polyanskaya LM, Larin NV, Larin VN. Changes 555 in the humus status and the structure of the microbial biomass in hydrogen exhalation 556 places. Eurasian Soil Sci 2013;46:135-44.

[47] Teixeira AH De C, Bastiaanssen WGM, Ahmad MD, Bos MG. Reviewing SEBAL input parameters for assessing evapotranspiration and water productivity for the MowMiddle São Francisco River basin, Brazil. Part A: calibration and validation. Agric For Meteorol 2009;149:462-76.

[48] Truche L, Joubert G, Dargent M, Martz P, Cathelineau M, Rigaudier T, Quirt D. Clay minerals trap hydrogen in the Earth's crust: evidence from the Cigar Lake uranium deposit, Athabasca. Earth Planet Sci Lett 2018;493:186-97.

[49] Vacquand C, Deville E, Beaumont V, Guyot F, Sissmann O, Pillot D, Arcilla C, Prinzhofer A. Reduced gas seepages in ophiolitic complexes: evidences for multiple origins of the $\mathrm{H}_{2}-\mathrm{CH}_{4}-\mathrm{N}_{2}$ gas mixtures. Geochem Cosmochim Acta 2018;223:437-61.

[50] Vinukollu RK, Wood EF, Ferguson CR, Fisher JB. Global estimates of evapotranspiration for climate studies using multi-sensor remote sensing data: evaluation of three process-based approaches. Rem Sens Environ 2011;115:801-23.

[51] Welhan JA, Craig H. Methane and hydrogen in East pacific rise hydrothermal fluids. Geophys Res Lett 1979;6:829-31.

[52] Zgonnik V, Beaumont V, Deville E, Larin N, Pillot D, Farrell K. Evidences for natural hydrogen seepages associated with rounded subsident structures: the Carolina bays (Northern Carolina, USA). Prog Earth Planet Sci 2015;2:31. https://doi. org/10.1186/s40645-015-0062-5. 